\title{
IDENTIFICATION OF CORTACTIN MOLECULAR FORMS IN HUMAN URINE AND THEIR POSSIBLE DIAGNOSTIC VALUE
}

\author{
M. STARYKOVYCH ${ }^{1}$, S. SOUCHELNYTSKYI ${ }^{2}$, O. FAYURA ${ }^{3}$, \\ O. ABRAHAMOVYCH ${ }^{3}$, M. ABRAHAMOVYCH ${ }^{3}$, \\ N. LUKAVETSKYY ${ }^{4}$, R. STOIKA ${ }^{1}, Y . K I T^{1 凶}$ \\ ${ }^{1}$ Department of Regulation of Cell Proliferation and Apoptosis, \\ Institute of Cell Biology, National Academy of Sciences of Ukraine; \\ ${ }^{2}$ College of Medicine, QU Health, Qatar University, Doha, Qatar; \\ ${ }^{3}$ Department of Internal Medicine № 1, Danylo Halytsky Lviv National \\ Medical University, Ukraine; \\ ${ }^{4}$ Lviv State Oncology Regional Treatment and Diagnostic Center, Lviv, Ukraine; \\ 区e-mail: kit@cellbiol.lviv.ua
}

Received: 14 September 2020; Accepted: 07 July 2021

The protein composition of human urine reflects changes in the biochemical and physiological status of an individual and has an essential diagnostic value. Using precipitation/extraction methods we isolated a protein with $\mathrm{Mr} \sim 100 \mathrm{kDa}$ in a human urine. MALDI TOF/TOF mass spectrometry identified this protein as human Src protein kinase substrate cortactin (UniProtKB/Swiss-Prot: Q14247). Screening of urine samples using Western blotting with specific anti-human cortactin antibodies revealed different proteins immunologically related to cortactin in healthy humans and patients with liver cirrhosis and lung cancer diseases. These data suggest that the level of cortacins isoform in urine might serve as a potential marker for testing acute and systemic diseases.

Ke y wo rd s: human urine, cortactins, liver cirrhosis, lung cancer.

$\mathrm{N}$ on-invasive ways of monitoring are enabled by introduction of numerous clinically useful diagnostic tests in response to treatment [1]. Human urine contains different proteins whose evaluation might have both diagnostic and prognostic value [1, 2]. Consequently, detection of novel urinary proteins could be beneficial to identify new markers of various acute and systemic diseases. Earlier, using TCA-acetone precipitation/ extracted procedure in combination with MALDI TOF/TOF and western blotting, we identified 46-48 kDa ("short") form of the unconventional myosin lc (sMyo1C) whose elevated level in human blood serum was associated with some autoimmune and hemato-oncological diseases [3, 4]. Using this approach, we attempted to identify novel urine proteins possessing diagnostic value. Here, we report about identification in human urine of different proteins which immunologically are related to cytoskeleton protein cortactin. This protein is located in the cytoplasm of all cell types and can be activated by the external stimuli that lead to polymerization and rearrangement of actin cytoskeleton [5]. Cortactin is important for promoting lamellipodia formation, invadopodia formation, cell migration. and endocytosis [5-7]. Many studies have documented a role for this protein in promoting cell motility and invasion, including a critical role in invadopodia, actin richsubcellular protrusions associated with degradation of the extracellular matrix $[7,8]$. The obtained data demonstrate that the level of different cortactin molecular forms in human urine might serve as a potential diagnostic and prognostic marker of liver cirrhosis and lung cancer.

(C) 2021 Starykovych M.et al. This is an open-access article distributed under the terms of the Creative Commons Attribution License, which permits unrestricted use, distribution, and reproduction in any medium, provided the original author and source are credited. 


\section{Materials and Methods}

Ethical approval. All procedures that involve human participants were performed in accordance with the ethical standards of the institutional and national research committee and with the $1964 \mathrm{Hel}-$ sinki declaration and its later amendments or comparable ethical standards.

Human urine samples. Urine samples were obtained from patients with 12 liver cirrhosis, 12 lung cancer patients and 10 healthy volunteers $25-55$ years old without diagnosed chronic diseases. The samples were collected under the approval of the BioEthics Review Board of the Danylo Halytsky Lviv National Medical University in accordance with the regulations of the Ministry of Health of Ukraine. A documented consent was obtained from all patients included in the study, and the form of the informed consent was approved by the Bio-Ethics Review Board of the Danylo Halytsky Lviv National Medical University (Protocol No. 2 dated by February 15, 2016).

Preparation of urine protein samples. The samples for MALDI TOF mass spectrometry were prepared according to following protocol: to $2 \mathrm{ml}$ of fresh urine was added $100 \%$ TCA to $10 \%$ of final concentration [3]. After 30 min incubation on ice, the solution was centrifuged for $15 \mathrm{~min}$ at $10,000 \mathrm{~g}$. The supernatant containing TCA-soluble compounds was isolated and mixed 1:6 with acetone, followed by incubation at $-20^{\circ} \mathrm{C}$ for $18 \mathrm{~h}$. The precipitate was pelleted by centrifugation for $10 \mathrm{~min}$ at $10,000 \mathrm{~g}$. The pellet was diluted in distilled water and proteins were separated by the SDS-electrophoresis. To detect the cortactin molecular forms in human urine samples, $1 \mathrm{ml}$ the fresh urine was centrifuged for $15 \mathrm{~min}$ at $10,000 \mathrm{~g}$. To $0.2 \mathrm{ml}$ of urine aliquots $0.8 \mathrm{ml}$ acetone were added followed by incubation at $-20^{\circ} \mathrm{C}$ for $18 \mathrm{~h}$. The precipitate was pelleted by centrifugation for $10 \mathrm{~min}$ at $10,000 \mathrm{~g}$. The pellet was diluted in distilled water and proteins were separated by SDSelectrophoresis, followed by Western blotting.

Detection of cortactin molecular forms in the enriched exosome fraction isolated from urine samples. To obtain enriched exosome fractions, $200 \mathrm{ml}$ urine sample of the clinically healthy person were centrifuged for $30 \mathrm{~min}$ at $3.700 \mathrm{~g}$ and supernatants were filtered through a syringe filter $0.1 \mu$ (Amicon, USA). The filter was washed with $5 \mathrm{ml} \mathrm{PBS}$, and proteins were eluted drop by drop using denaturing buffer (20 mM Tris-HCl, pH 6.8, 1\% SDS-Na). Collected eluate was separated by SDS-electrophoresis and evaluated by the Western-blot analysis.
SDS-electrophoresis and Western-blot analysis. SDS-electrophoresis in 12\% PAG [8] of urine proteins was followed by gel staining with Coomassie Brilliant Blue G. For Western blot analysis, proteins were transferred from the gel onto a nitrocellulose membrane. The membranes were blocked $\left(1 \mathrm{~h}\right.$ at $\left.20^{\circ} \mathrm{C}\right)$ with $5 \%$ non-fat milk in the PBS buffer containing $0.05 \%$ Tween-20. The blots were washed with PBS-Tween-20, three times for 5 min each, and then probed with the specific primary antibodies. To identify electrophoretic forms of cortactin in human urine, mouse anti-human cortactin monoclonal antibody (R\&D system, Catalog no. MAB6096) were used. The membrane was incubated overnight at $4^{\circ} \mathrm{C}$ with antibodies diluted 1:1,000. Corresponding antimouse secondary antibodies were used for ECL detection. Generated images were scanned, digitalized, and images were quantified using ImageJ software.

MALDI-TOF mass spectrometry. Individual electrophoretic protein bands were excised from the gel and subjected to the in-gel trypsin digestion as was described earlier [9]. To identify the proteins, their tryptic digests were subjected to peptide mass fingerprinting (PMF). MALDI TOF/TOF mass spectrometry was performed on a Shimadzu-7090 instrument (Shimadzu/Kratos, the UK). Samples were mixed with alpha-cyano-4-hydroxy-cinnamic acid, and loaded on a metal target plate. Mass spectrum was collected in the positive mode. i.e. for $\mathrm{MH}+$ ions. Internal calibration was performed with tryptic peptides generate upon auto-digestion of trypsin added to samples (842.51, 1045.56 and 2211.10 Da). Collected mass spectra were used for searches with Mascot tool of NCBInr database. Search criteria were as follow: no limitations of species and pI, mass selection as for 20 to $200 \mathrm{kDa}, \mathrm{MH}+$, complete alkylation of Cys, partial oxidation of Met, one missed cleavage by trypsin, and tolerance of 0.5 Da.

\section{Results and Discussion}

TCA-extracted urine proteins and their characterization. For isolation of the TCA-extracted proteins from human urine, a procedure used initially for obtaining TCA-soluble proteins from the blood serum was used. The urine was mixed with TCA to a final $10 \%$ TCA concentration, precipitate was removed by centrifugation, and TCA-soluble compounds were precipitated with acetone at 1:6 ratio. The figure 1 shows a typical SDS-PAG electrophoretic profile of the acetone precipitated proteins. We observed that the TCA-soluble fractions contained 

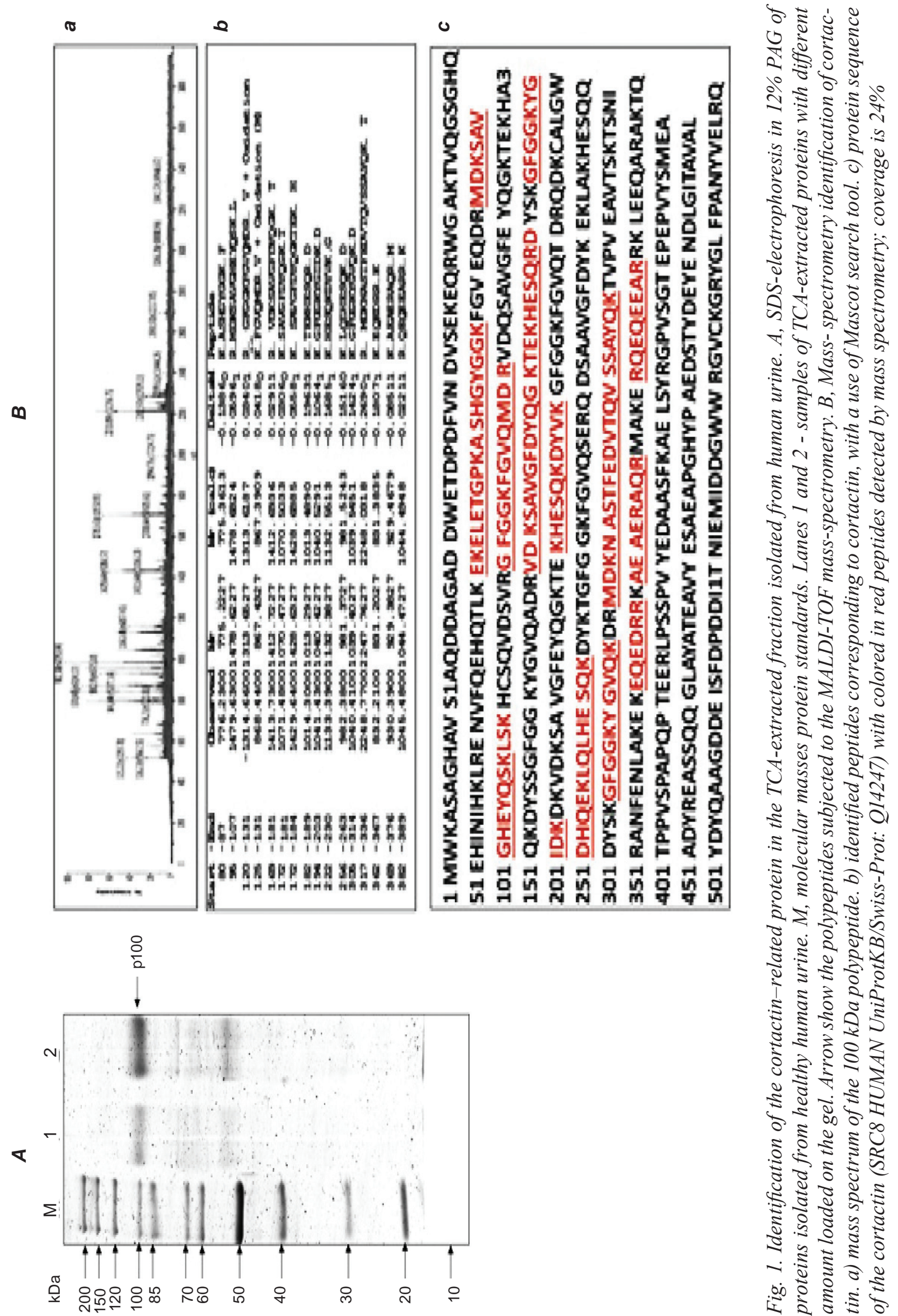
$\boldsymbol{A}$

B

C

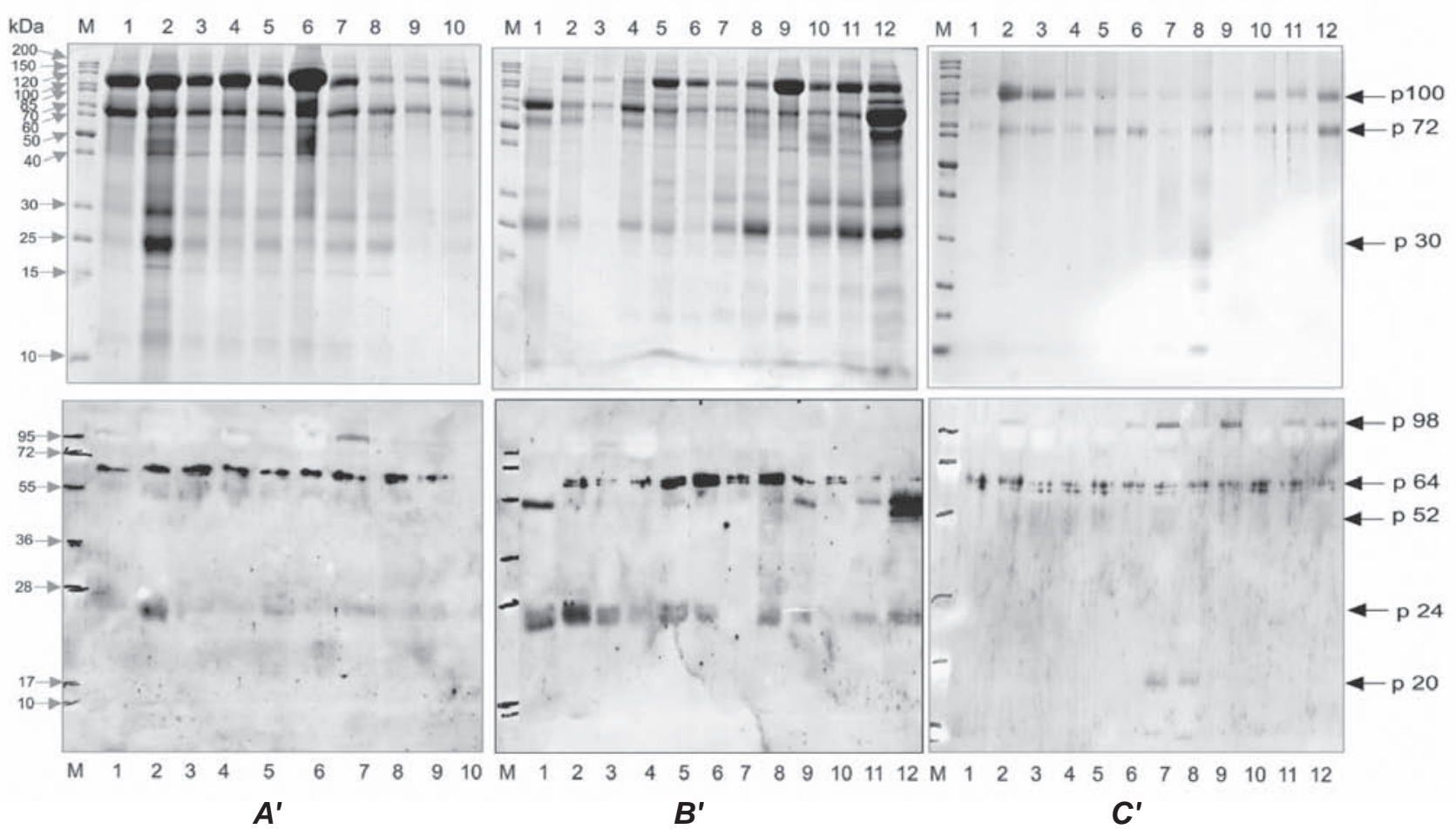

Fig. 2. Identification of cortactin molecular forms in urine samples of healthy human donors (A and $\left.\mathbf{A}^{\prime}\right)$, patients with cirrhosis (B and $\mathbf{B}^{\prime}$ ), and lung cancer (C and $\left.\boldsymbol{C}^{\prime}\right)$. A, B, C-SDS-electroperesis in 12\% PAG following the gels staining with Coomassie G 250. M-molecular mass protein standard. A', B', C' - Westernblotting using a mouse anti-human cortactin monoclonal antibody R\&D system, Catalog no. MAB6096). Mposition of the proteins molecular mass standards $(95,72,55,36,28,17,10 \mathrm{kDa})$ marked on the nitrocellulose membrane. On the right side, the position of the proteins immunologically related with cortactins is shown

proteins with the molecular mass of $100 \mathrm{kDa}$ (Fig. 1, A). To identify this polypeptide, MALDI TOF/TOF mass spectrometry identification was performed. Peptide mass fingerprinting with use of the Mascot searching tool identified the $100 \mathrm{kDa}$ protein as the Src substrate cortactin (UniProtKB/Swiss-Prot: Q14247) (Fig. 1, B). Sixteen of the peptides presented $24 \%$ of the sequence of the cortactin, with the significance set by $P<0.5$, and a score value 54 .

Identification of cortactin molecular form in the urine protein pools. To check whether the cortactine molecular forms are present in human urine, we performed the immunoblotting study. Urine samples were obtained from 10 healthy donors, 12 liver cirrhosis patients and 12 lung cancer patients. TCAsoluble proteins of these samples were separated by SDS-electrophoresis followed by Western blotting using specific anti-cortactin antibodies for detection (see Material and Methods section). Electrophoresis demonstrated that the proteins isolated from urine samples of healthy donors (Fig. 3, A), as well as of the patients suffering liver cirrhosis and lung cancer (Fig. 3, $A, B$ and $C$ ) contain polypeptides ranged in between $20 \mathrm{kDa}$ and $120 \mathrm{kDa}$.

Proteins with molecular masses of 100,72 , and $30 \mathrm{kDa}$ were found to be the most abundant. Western-blotting using anti-cortactin antibodies detected the polypeptides ranged in between $98 \mathrm{kDa}$ and $20 \mathrm{kDa}$ in different urine samples of healthy volunteers and patients with of liver cirrhosis and lung cancer (Fig. 3, $A, B$ and $C$ ). It was found that all 12 urine samples of healthy humans contained cortactin molecular forms with molecular masses $64 \mathrm{kDa}$. In addition to the $64 \mathrm{kDa}$ protein, in two samples of healthy human, protein bands with molecular mass $24 \mathrm{kDa}$ and $98 \mathrm{kDa}$, respectively were also detected (Fig. 3, A', lanes 2 and 8). We also explored the distribution of cortactin isoforms in urine samples of 12 liver cirrhosis patients. It was found that 11 of 12 patients contain $64 \mathrm{kDa}$ protein (Fig. 3, 
$B$, lanes 2-12), also detected in healthy donors. Among samples of liver cirrhosis patients, 4 of them contained $55 \mathrm{kDa}$ polypeptide earlier not detected in healthy donors (Fig. 3, B, lanes 1, 9, 11, 12). It should be noted, that $24 \mathrm{kDa}$ protein that was detected only in 1 of 10 urinary samples of healthy donors was detected in 10 cirrhosis patients (Fig. 3, B, lanes 1, 2, 3 , 5, 7, 8, 11, 12). Fig. 3, C’ (lanes 1-12) demonstrates a distribution of cortactin isoforms in urine samples of patients with oncologic diseases. It was found that all of them, similarly to healthy donors, contain $64 \mathrm{kDa}$ protein (Fig. 3). In contrast to healthy donors and cirrhosis patients (Fig 3, $A^{\prime}$ and $B^{\prime}$ ), in 6 samples of 12 lung cancer patients were detected cortactin-like 98 kDa protein (Fig. 3, C', lanes 2, 6, 7, 9, 11, 12). It has to be noted that two samples of lung cancer patients (Fig. 3, C', lanes 7, 8) consisted of $20 \mathrm{kDa}$ cortactinrelated proteins which were not detected in urine samples of healthy human and cirrhosis patients.
Identification of cortactin molecular forms in the exosome fraction isolated from human urine. Origin of cortactin isoforms in the human urine remains unclear. We proposed that one of the mechanisms could be associated with the exosomes in urine. To explore this hypothesis, we isolated the exosome fraction from $200 \mathrm{ml}$ human urine, using differential centrifugation followed ultrafiltration [11]. Fig. 3 presents the results of electrophoretic and western blot-analysis of isolated exosome fractions using anti-cortactin antibodies. We observed that the exosome fractions indeed contained proteins with molecular masses of 65, 55 and $36 \mathrm{kDa}$ and are recognized by anti-cortactin antibodies.

Human urine has a potential non-invasive diagnostic value [1]. Earlier, we used the method of isolation of TCA-soluble compounds in human blood serum and identified a novel $48 \mathrm{kDa}$ Myo 1c protein [4,5] and Ser-Pro-Cys peptide (prosercyn) as protein biomarkers of the multiple sclerosis [12].
A

\section{Human urine} $(20 \mathrm{ml})$

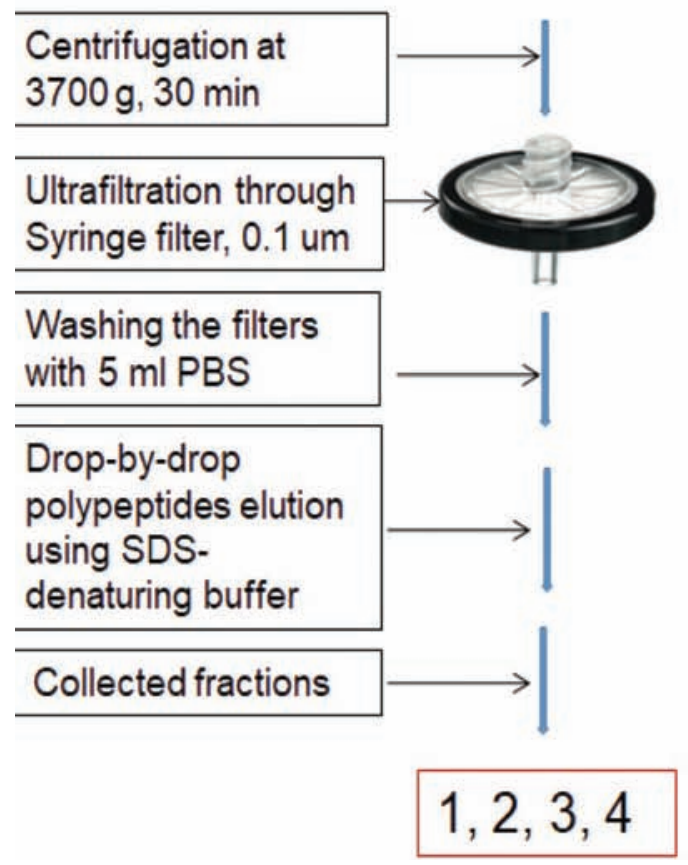

B

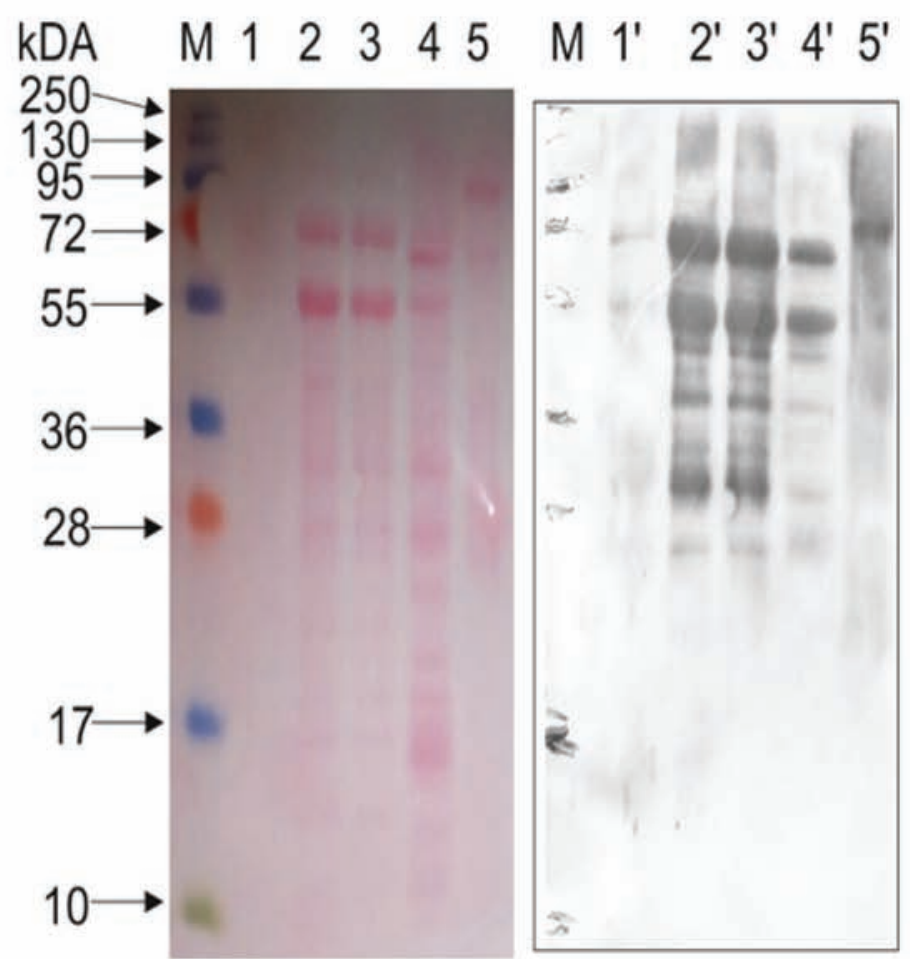

Fig. 3. Identification of cortactin molecular forms in human urine exosome. A, scheme of the exosome isolation by ultrafiltration of healthy human urine sample through syringe filter 0.1 um Amicon, USA (see the details in "Materials and Methods"). B, identification of cortactin molecular forms in the obtained fractions by Western blotting using mouse anti-human cortactin monoclonal antibodies (see "Material and Methods). Lanes 1-4, the fractions eluted drop by drop from Amicon filter using SDS-denaturing buffer. Lane 5, the acetone precipitation debris of the human urine sample. $M$ - position of protein molecular mass standards 
We also used this approaches to study human urine for present of TCA-soluble proteins. SDS-PAG electrophoresis followed MALDI TOF/TOF mass spectrometry revealed in the healthy human urine sample $100 \mathrm{kDa}$ protein identified as cortical actin binding protein (cortactin). Cortactin is a monomeric protein located in the cytoplasm of all cell types. It can be activated by the external stimuli to promote polymerization and rearrangement of the actin cytoskeleton, especially the actin cortex around the cellular periphery $[5,7]$.

Three molecular forms of the cortactin were described [13]. Cortactin-A, -B and -C had six, five, and four cortactin repeats, respectively. All cortactin's isoforms are able to bind to F-actin, but only cortactin-A demonstrated an F-actin-crosslinking activity. In addition, cortactin-A was able to bind along the side of the F-actin [5-8].

Screening of urine protein content in healthy people and patients with liver cirrhosis and lung cancer allowed us to identify different molecular forms of the cortactins. Our preliminary data suggest that increasing of the level of $24.0 \mathrm{kDa}$ proteins and the appearance of $52.0 \mathrm{kDa}$ proteins in human urine might be associated with the appearance of the decompensated stage of liver cirrhosis. However, the assessment of their diagnostic value needs further studies [14]. This fact suggests that the distribution of cortactin molecular forms in the urine might have a diagnostic and/or prognostic significance.

The origin of different cortactin molecular forms in human urine remains unknown. In our opinion, there are two ways of their appearance in human urine. Recently, we discovered for the first time in human blood serum three polypeptides with molecular weights of 200,55 , and $28 \mathrm{kDa}$ with immunoreactivity against monospecific anti-cortactin antibodies [15]. Consequently, there is a possibility that urinary cortactin molecular forms can originate from blood serum.

It is well known that cortactin promotes exosomes secretion in different human cells [16, 17]. Our data demonstrate that some cortactin molecular forms might be present in a fraction of the urinary exosomes. Consequently, it is possible that urinary cortactins of different molecular forms could be linked with urinary exosomes.

The urinary exosomes have been secreted by the epithelial cell types lining the urinary tract system in human [18]. Exosomes are an attractive source for biomarker discovery, as they contain mo- lecular constituents of their cell of origin, including proteins and genetic materials, and they can be isolated in a non-invasive manner $[19,20]$. Our consequent studies of the content of the various forms of cortactin in urine exosomes could clarify this issue.

Conclusion. Investigation of protein content in urine using MALDI-TOFF mas-spectrometry in a combination with western blot analysis identified various molecular forms of cortactin that differ in healthy people, patients with liver cirrhosis and lung cancer. We suggest that these polypeptides could serve as potential molecular biomarkers of the diseases. The reported data provide a basis for further large scale experimental investigation and clinical trial of cortactin role.

Conflict of interest. Authors have completed the Unified Conflicts of Interest form at http://ukrbiochemjournal.org/wp-content/uploads/2018/12/ coi_disclosure.pdf and declare no conflict of interest.

Funding. This work was partially financial supported by the Target Complex Interdisciplinary Research Program of NAS of Ukrain: "Creation of the newest preventive technologies of treatment of acute rheumatic diseases by suppression of action of proinflammatory components of dying cells". Grant number 32-16.

\section{ІДЕНТИФІКАЦІЯ МОЛЕКУЛЯРНИХ ФОРМ КОРТАКТИНУ В СЕЧІ ЛЮДИНИ ТА ЇХНЄ МОЖЛИВЕ ДІАГНОСТИЧНЕ ЗНАЧЕННЯ}

\section{М. Старикович 1 , С. Сушельницький르, О. Фаюра ${ }^{3}$ О. Абрагамович ${ }^{3}$, М. Абрагамович, Н. Лукавецький Р. Стойка ${ }^{1}$ Ю. Кім ${ }^{1 凶}$}

${ }^{1}$ Відділ регуляції клітинної проліферації та апоптозу, Інститут клітинної біології НАН України, Львів;

${ }^{2}$ Медичний коледж, QU Health, Катарський університет, Доха, Катар;

${ }^{3}$ Кафедра внутрішніх хвороб № 1, Львівський національний медичний університет імені Данила Галицького, Україна;

4Львівський державний онкологічний обласний лікувально-діагностичний центр, Львів, Україна; 凶e-mail: kit@cellbiol.lviv.ua

Протеїновий склад сечі людини відображає зміни біохімічного та фізіологічного статусу та має важливе діагностичне значення. За допомогою методів осадження/екстракції ми ви- 
ділили протеїн із $\mathrm{Mr} \sim 100$ кДа із сечі людини. Методом мас-спектрометрії MALDI TOF/TOF ідентифіковано цей протеїн як субстрат протеїнкінази людського Src кортактину (UniProtKB/ Swiss-Prot: Q14247). Скринінг зразків методом вестерн-блоту 3 використанням специфічних людських антитіл до коктактину виявив різні протеїни, імунологічно пов'язані $з$ кортактином у здорових людей та пацієнтів із цирозом печінки та раком легенів. Ці дані свідчать про те, що вміст ізоформ кортактинів у сечі може слугувати потенційним маркером для тестування гострих та системних захворювань.

Ключов і слов а: сеча людини, кортактини, цироз печінки, рак легенів.

\section{References}

1. Hu S, Loo JA, Wong DT. Human body fluid proteome analysis. Proteomics. 2006; 6(23): 6326-6353.

2. Selevsek N, Matondo M, Carbayo MS, Aebersold R, Domon B. Systematic quantification of peptides/proteins in urine using selected reaction monitoring. Proteomics. 2011; 11(6): 1135-1147.

3. Gajbhiye A, Dabhi R, Taunk K, Vannuruswamy G, RoyChoudhury S, Adhav R, Seal S, Mane A, Bayatigeri S, Santra MK, Chaudhury K, Rapole S. Urinary proteome alterations in HER2 enriched breast cancer revealed by multipronged quantitative proteomics. Proteomics. 2016; 16(17): 2403-2418.

4. Myronovkij S, Negrych $\mathrm{N}$, Nehrych $\mathrm{T}$, Redowicz MJ, Souchelnytskyi S, Stoika R, Kit Y. Identification of a $48 \mathrm{kDa}$ form of unconventional myosin 1c in blood serum of patients with autoimmune diseases. Biochem Biophys Rep. 2016; 5: 175-179.

5. Kit Y, Myronovsky S, Starykovych M, Nehrych T, Negrych N, Shorobura M, Nehrych O, Shalay O, Tolstyak Y, Havryluk A, Kril I, Tkachuk S, Stepanenko L, Stoika R. A Short Form of Unconventional Myosin 1C in a Human Blood Serum: Discovery and Investigation. In "Myosin: Biosynthesis, Classes and Function” Eds.: David Broadbent / Nova Sci. Publ. Inc. Hauppauge NY. 2018, 159-175 p.

6. Cosen-Binker LI, Kapus A. Cortactin: the gray eminence of the cytoskeleton. Physiology (Bethesda). 2006; 21: 352-361.
7. Dudek SM, Jacobson JR, Chiang ET, Birukov KG, Wang P, Zhan X, Garcia JGN. Pulmonary endothelial cell barrier enhancement by sphingosine 1-phosphate: roles for cortactin and myosin light chain kinase. $J$ Biol Chem. 2004; 279(23): 24692-24700.

8. MacGrath SM, Koleske AJ. Cortactin in cell migration and cancer at a glance. $J$ Cell Sci. 2012; 125(Pt 7): 1621-1626.

9. Laemmli UK. Cleavage of structural proteins during the assembly of the head of bacteriophage T4. Nature. 1970; 227(5259): 680-685.

10. Zakharchenko O, Greenwood C, Lewandowska A, Hellman U, Alldridge L, Souchelnytskyi S. Meta-data analysis as a strategy to evaluate individual and common features of proteomic changes in breast cancer. Cancer Genomics Proteomics. 2011; 8(1): 1-14.

11. Merchant ML, Powell DW, Wilkey DW, Cummins TD, Deegens JK, Rood IM, McAfee KJ, Fleischer C, Klein E, Klein JB. Microfiltration isolation of human urinary exosomes for characterization by MS. Proteomics Clin Appl. 2010; 4(1): 84-96.

12. Myronovkij $\mathrm{S}$, Negrych $\mathrm{N}$, Nehrych $\mathrm{T}$, Tkachenko V, Souchelnytskyi S, Stoika R, Kit Y. Identification of SER-PRO-CYS Peptide in Blood Serum of Multiple Sclerosis Patients. Protein Pept Lett. 2016; 23(9): 808-811.

13. Ohoka Y, Takai Y. Isolation and characterization of cortactin isoforms and a novel cortactinbinding protein, CBP90. Genes Cells. 1998; 3(9): 603-612.

14. Starykovych M, Antonyuk V, Nehrych T, Negrych N, Horák D, Souchelnytskyi S, Kit O, Stoika R, Ki Y. Isolation and identification in human blood serum of the proteins possessing the ability to bind with $48 \mathrm{kDa}$ form of unconventional myosin 1c and their possible diagnostic and prognostic value. Biomed Chromatogr. 2021; 35(4): e5029.

15. Manko N, Starykovych M, Bobak Y, Stoika R, Richter V, Koval O, Lavrik I, Horák D, Souchelnytskyi S, Kit Y. The purification and identification of human blood serum proteins with affinity to the antitumor active RL2 lactaptin using magnetic microparticles. Biomed Chromatogr. 2019; 33(11): e4647.

16. Daly RJ. Cortactin signalling and dynamic actin networks. Biochem J. 2004; 382(Pt 1): 13-25. 
17. Sinha S, Hoshino D, Hong NH, Kirkbride KC, Grega-Larson NE, Seiki M, Tyska MJ, Weaver AM. Cortactin promotes exosome secretion by controlling branched actin dynamics. J Cell Biol. 2016; 214(2): 197-213.

18. Huebner AR, Somparn $\mathrm{P}$, Benjachat $\mathrm{T}$, Leelahavanichkul A, Avihingsanon Y, Fenton RA, Pisitkun T. Exosomes in urine biomarker discovery. Adv Exp Med Biol. 2015; 845: 43-58.

19. Bruschi M, Santucci L, Ravera S, Candiano G, Bartolucci M, Calzia D, Lavarello C, Inglese E, Ramenghi LA, Petretto A, Ghiggeri GM, Panfoli I. Human urinary exosome proteome unveils its aerobic respiratory ability. $J$ Proteomics. 2016; 136: 25-34. 